\title{
Capromab Pendetide
}

National Cancer Institute

\section{Source}

National Cancer Institute. Capromab Pendetide. NCI Thesaurus. Code C2209.

An immunoconjug ate of the murine monoclonal antibody, 7E11-C5.3 (Capromab),

conjug ated to the linker-chelator, glycyl-tyrosyl-( $\mathrm{N}$,-diethylenetriaminepentaacetic acid)lysine hydrochloride (GYK-DTPA-HCI). Capromab, an IgG1 kappa immunoglobulin, binds specifically to a cytoplasmic epitope of prostate-specific membrane glycoprotein (PSMA) that is only expressed by prostatic epithelial cells (benign and malignant). Capromab pendetide can be used in diagnosis or detection of prostate cancer when labeled with Indium I-111, which emits gamma radiation and X-Ray photons that can be captured by gamma camera allowing imaging of PMSA expressing tissues. 